\title{
Nipah Virus Sequences from Humans and Bats during Nipah Outbreak, Kerala, India, 2018
}

\author{
Pragya D. Yadav, Anita M. Shete, \\ G. Arun Kumar, Prasad Sarkale, \\ Rima R. Sahay, Chandni Radhakrishnan, \\ Rajen Lakra, Prachi Pardeshi, Nivedita Gupta, \\ Raman R. Gangakhedkar, V.R. Rajendran, \\ Rajeev Sadanandan, Devendra T. Mourya
}

We retrieved Nipah virus (NiV) sequences from 4 human and 3 fruit bat (Pteropus medius) samples from a 2018 outbreak in Kerala, India. Phylogenetic analysis demonstrated that NiV from humans was $96.15 \%$ similar to a Bangladesh strain but $99.7 \%-100 \%$ similar to virus from Pteropus spp. bats, indicating bats were the source of the outbreak.

$\mathrm{N}$ ipah virus (NiV) was first reported from Malaysia in 1999 (1). Additional NiV outbreaks have occurred in Bangladesh (2-4) and India (5,6). NiV is a negativesense enveloped RNA encoding for 6 genes (nucleocapsid, phosphoprotein, matrix, fusion protein, glycoprotein, and polymerase) $(7,8)$. Two NiV clades have been proposed: B genotype, predominantly found circulating in Bangladesh, and M genotype in Malaysia and Cambodia (9). NiV-positive fruit bats (Pteropus medius) were found in West Bengal, Assam, and Haryana states in India, posing a possible source of NiV infection in humans (10-12).

\section{The Study}

In May 2018, the Indian Council of Medical Research-National Institute of Virology (ICMR-NIV; Pune, India) received clinical specimens (throat swab, urine, and serum) from 3 persons from Kozhikode district, Kerala state, who were suspected to have NiV infection. Their clinical signs and symptoms were moderate to high-grade fever, headache, vomiting, myalgia, cough, and rapidly progressing breathlessness. Neurologic symptoms included altered

Author affiliations: Indian Council of Medical Research-National Institute of Virology, Pune, India (P.D. Yadav, A.M. Shete, P. Sarkale, R.R. Sahay, R. Lakra, P. Pardeshi, D.T. Mourya); Manipal Centre for Virus Research, Manipal, India (G.A. Kumar); Government Medical College Kozhikode, Kozhikode, India (C. Radhakrishnan, V.R. Rajendran); Indian Council of Medical Research, New Delhi, India (N. Gupta, R.R. Gangakhedkar); Health \& Family Welfare, Kerala (R. Sadanandan)

DOI: https://doi.org/10.3201/eid2505.181076 sensorium and seizures. Details of the index case-patient and all secondary case-patients have been described (13).

We tested clinical samples from 9 secondary case-patients (Table 1, https://wwwnc.cdc.gov/EID/article/25/5/181076-T1.htm) for NiV using quantitative reverse transcription PCR (RT-PCR), nested RT-PCR, and IgM and IgG ELISA $(4,5,11-14)$. ThenestedRT-PCRamplification was performed using first set primers NipahNF311665'-CGTGGTTATCTTGAACCTATGTACTTCAG-3' and Nipahreverse1771 5'-CGCAACTTTAATGTAATTGGTCCCTTAGTG-3' and nested set primers NipahNF45-1342 5'-CAGAGAAGCTAAATTTGCTGCAGGAGG-3' and NipahN168455'-TCACACATCAGCTCTGACAAAGTCAAG-3'. These reactions were conducted using SuperScript III SingleStep RT-PCR system with PlatinumTaq High-fidelity (https://www.thermofisher.com).

We attempted to isolate virus from 26 specimens from 9 Nipah-confirmed case-patients and $1 \mathrm{NiV}$-negative patient by processing throat swab, lung tissue, urine, and serum specimens in the Biosafety Level 4 laboratory of ICMR-NIV, as described previously (14) (Table 1). We inoculated $100 \mu \mathrm{L}$ of each sample into a 24 -well culture plate of Vero (ATCC, CCL-81) cells in $1 \mathrm{ml}$ of Eagle minimal essential growth medium containing $10 \%$ fetal calf serum in each well. The culture plate was incubated at $37^{\circ} \mathrm{C}$ with $5 \% \mathrm{CO}_{2}$. All culture fluid was passaged 4 times, irrespective of showing cytopathic effect. We adjusted urine sample $\mathrm{pH}$ to 7.4 using $1 \mathrm{~N}$ sodium hydroxide before proceeding to virus isolation.

To determine the possible role of bats in NiV transmission in this outbreak, we captured bats from the area near the index case-patient's house using specialized nets, 21-30 days after illness onset in the index case-patient. Two species of bats, the fruit bat (Pteropus medius; $\mathrm{n}=$ 52 ) and Leschenault's rousette (Rousettus leschenaulti; $\mathrm{n}=$ 12 ), as well as 5 birds, were trapped. We euthanized them, collected rectal and throat swab specimens in the field, then transported these animals in a liquid nitrogen transport container to ICMR-NIV. The animals were dissected in the containment laboratory, and organs (lung, spleen/liver, kidney, intestine, brain) were collected. All specimens were tested by quantitative and nested RT-PCR.

We conducted next-generation sequencing (NGS) for each positive sample with a minimum volume of $250 \mu \mathrm{L}$, if available. We followed a library preparation method as 
described previously (15) and analyzed the paired-end reads from Illumina Miniseq (Illumina, https://www.illumina.com) using CLC Genomics Workbench software (QIAGEN, https://www.qiagen.com). We performed reference-based mapping to retrieve the $\mathrm{NiV}$ genome.

Only 1 throat swab sample (MCL-18-H-1088) inoculated in Vero CCL81 cells showed significant cellular morphologic changes, beginning at $8 \mathrm{~h}$ into 1 day postinfection (dpi) of passage 2 (Figure 1). We observed cell fusion and syncytial formation, and the frequency of the giant multinucleated cells increased as infection progressed. At $48 \mathrm{~h}$, cells with dendritic-like projections appeared, and at $64 \mathrm{~h}$, extensive cell damage occurred, and cells were detached. There was no obvious cell lysis, but we observed apoptosis such as nuclear invagination and membrane blebbing. The NiV isolate (MH523642) obtained showed a cycle threshold of 15.

Throat and rectal swab specimens from $13(25 \%)$ Pteropus sp. bats were positive for NiV; cycle threshold ranged from 28 to 37 . Of these positive bats, liver, spleen, or both of 3 bats was also NiV positive (product size 342 bp) by nested RT-PCR for partial nucleocapsid (N) gene. The product was sequenced and compared with Kerala human NiV sequences.

We retrieved 4 complete protein encoding regions of NiV using NGS from a secondary case-patient's throat swab sample (MH396625), lung tissue of a secondary case-patient (MH523640), and throat swab sample of a recovered case-patient (MH523641) and from a NiV isolate (from a throat swab specimen; MH523642) (Table 1). Approximately $18,100 \mathrm{nt}$ of the NiV genome was retrieved, encoding nucleocapsid, phosphoprotein, matrix, fusion, glycoprotein, and RNA polymerase protein. We tried NGS on positive NiV bat tissues/specimens, but attempts were unsuccessful.

We compared the retrieved genome sequence with the sequences available in GenBank and generated a
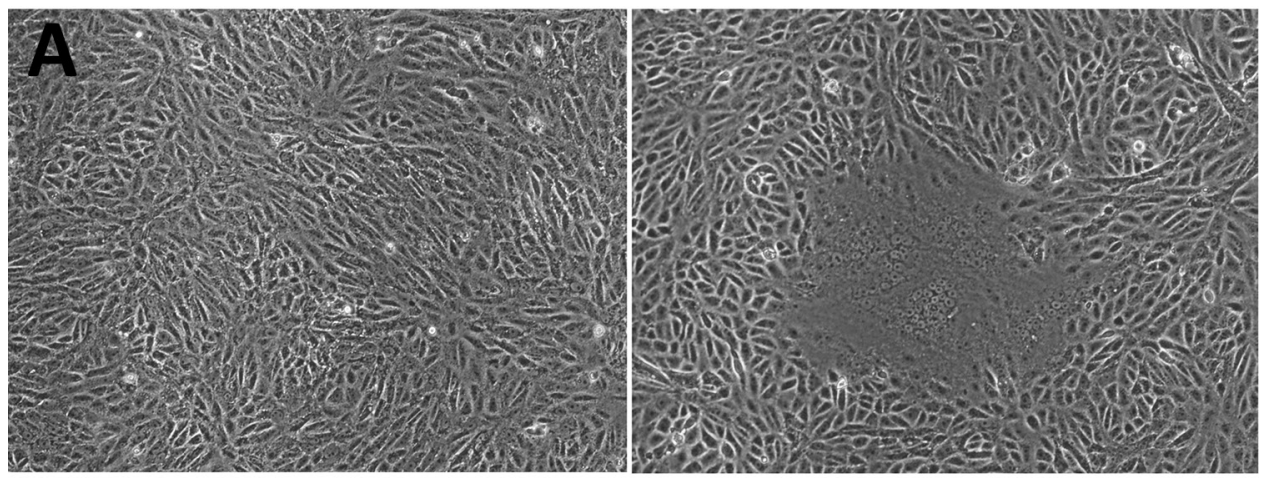

Figure 1. Cytopathic effect (CPE) of Nipah virus from throat swab samples of a patient in Kerala, India, 2018. Virus was inoculated into Vero CCL81 cells. A) CPE at postinfection days 1 (top) and 2 (bottom). Left panels depict the control cell; right panels depict the NiV-infected cell. B) NiV-infected cells. Original magnification $\times 10$.
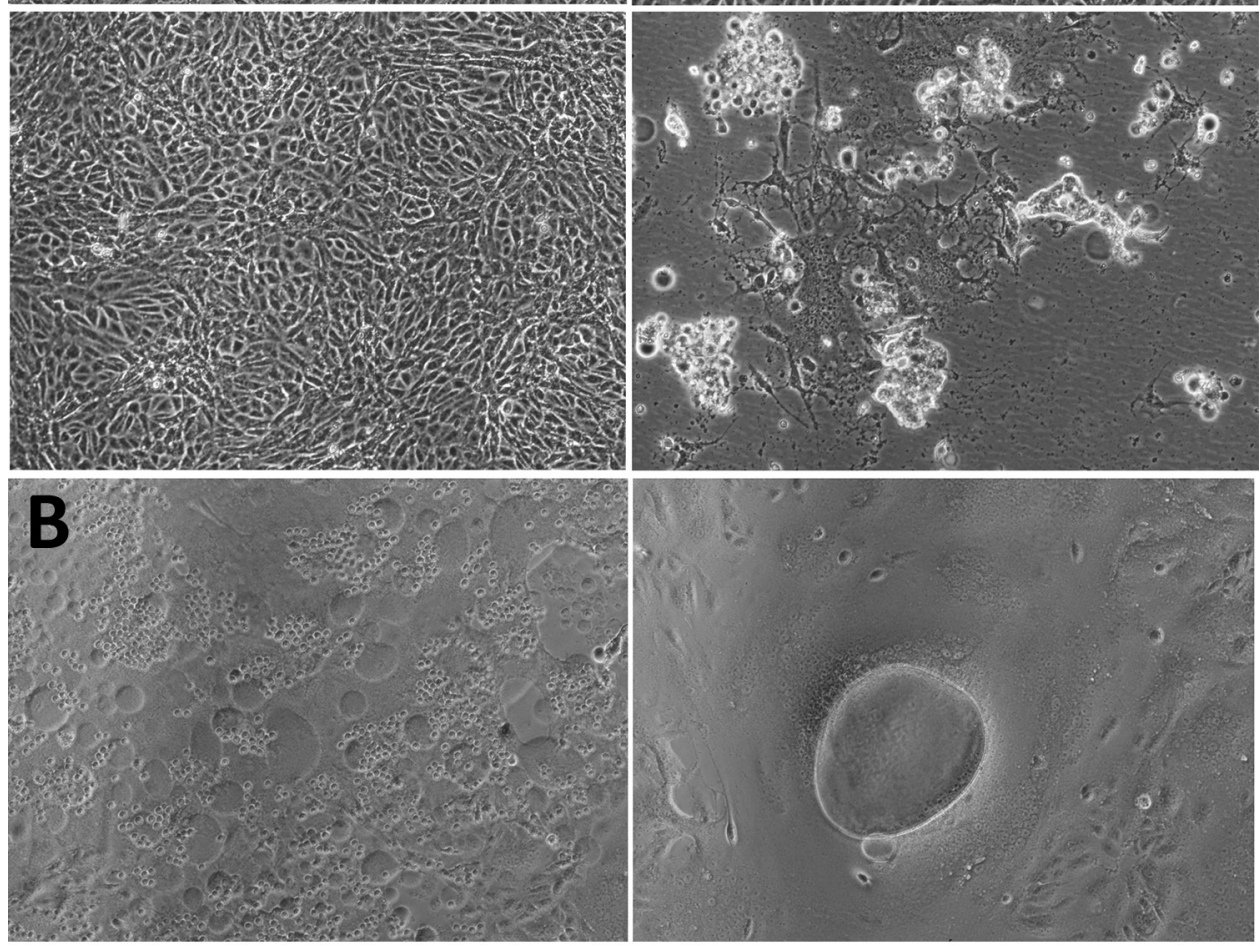
maximum-likelihood tree using the Tamura-Nei model on the complete coding region and a 316-nt region of the nucleocapsid region (Figure 2). Kerala NiV sequences from humans and bats clustered with the B clade, circulating in Bangladesh. The Nadia NiV sequence (GenBank accession no. FJ513078.1) showed higher similarity to and clustering with the Bangladesh viruses. However, the bat $\mathrm{N}$ gene sequences matched more closely with human sequences from Kerala than with others; Kerala human NiV sequences were $99.7 \%-100.0 \%$ homologous with the bat $\mathrm{NiV}$ sequences. The complete NiV genome of the Kerala strain had $85.14 \%-96.15 \%$ similarity with $\mathrm{M}$ and $\mathrm{B} \mathrm{NiV}$ genotype. Despite having $96.15 \%$ similarity to the Bangladesh strain, Kerala NiV strain forms a separate cluster (Table 2, https://wwwnc.cdc.gov/EID/article/25/5/181076-T2.htm; Appendix Table, https://wwwnc.cdc.gov/ EID/article/25/5/18-1076-App1.pdf).

\section{Conclusions}

In this outbreak, NGS helped identify the circulating NiV in Kerala as B genotype. We found the highest similarity between human $\mathrm{NiV}$ complete sequences from Kerala and $\mathrm{NiV}$ $\mathrm{N}$ gene sequences from Pteropus spp. fruit bats $(99.7 \%$ $100 \%$ ), compared with NiV sequences reported from Malaysia, Cambodia, and Bangladesh (85.14\%-96.15\%). This finding indicates that Pteropus spp. bats were most likely the source for human infection in this outbreak.
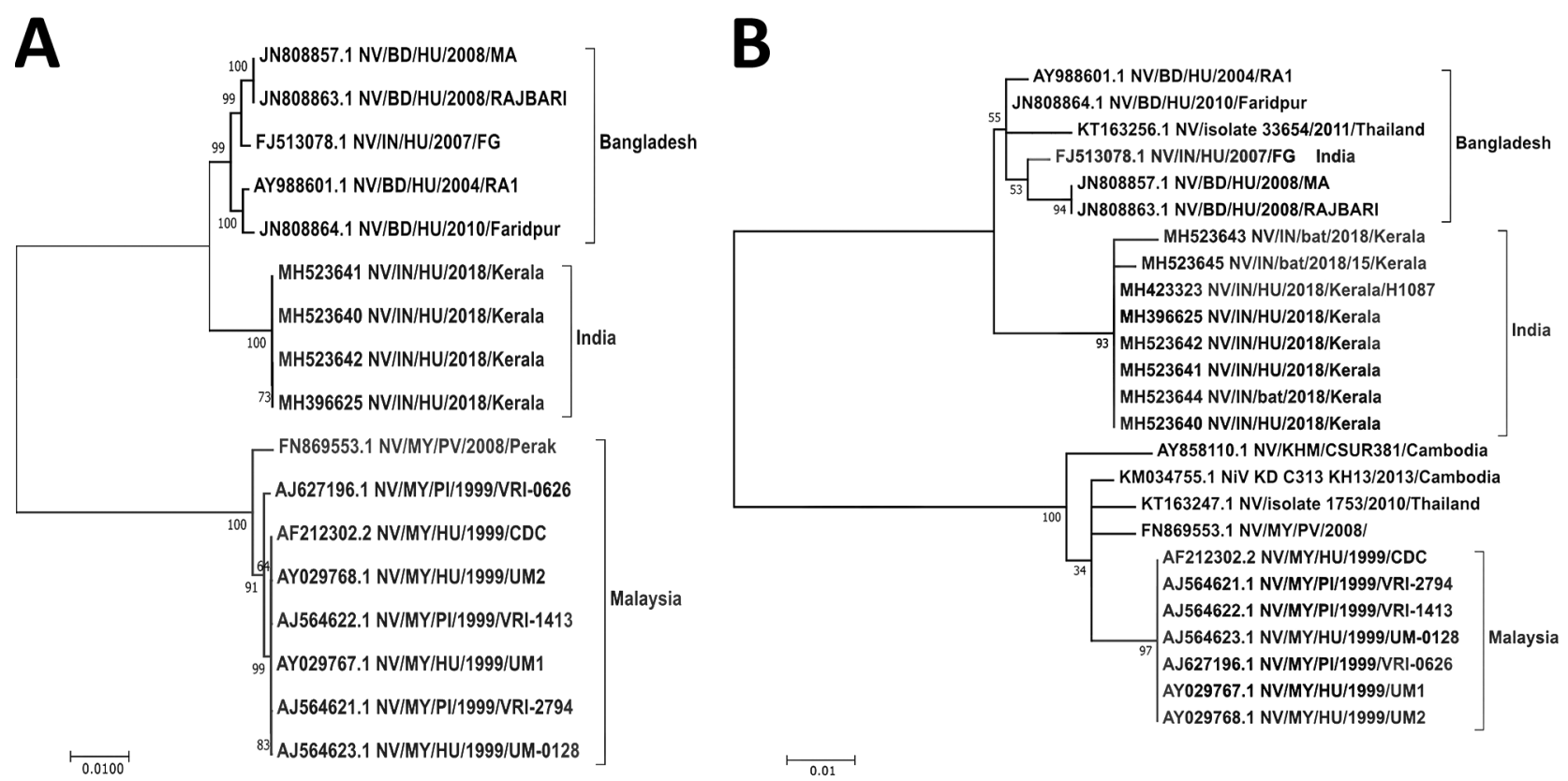

Figure 2. Maximum-likelihood phylogenetic tree of the nucleocapsid gene (region 1293-1608) of Nipah virus from Kerala, India, 2018, and reference sequences. A) Complete coding region. The evolution distance for 17 complete sequences was generated using the Tamura-Nei model plus gamma distance using different isolates. Bootstrap replication of 500 replication cycles was used for the statistical assessment of the generated tree. B) Partial nucleocapsid gene. The evolution distance for 25 nucleocapsid gene sequences of length $316 \mathrm{nt}$ was generated using the Tamura-Nei model plus gamma distance using different isolates. Bootstrap replication of 500-replication cycle was used for the statistical assessment of the generated tree. GenBank accession numbers are provided for all sequences. Scale bars indicate nucleotide substitutions per site.
Distinct clustering of Kerala sequences suggests that this strain may be circulating locally in bats and some evolution might exist that differentiates it from the northern Bangladesh/West Bengal strain. It may also suggest that the colony of bats sampled in this outbreak had active infection, but additional epidemiologic studies in bats may be needed to support this. Freeze-thawing of organs, lack of collection of fresh tissue samples in the field, or preserving tissues in virus transport medium might be the reasons for failure to retrieve the complete genome from bats.

Because of the lack of effective specific treatment or preventive vaccines for NiV infection, emphasis should be placed on containment of this virus. Strict isolation; biorisk mitigation; and hospital infection control policies, including the explicit use of personal protective equipment as a part of risk mitigation by healthcare workers, needs to be strengthened. Effective close contact and suspected NiV case surveillance will help in early diagnosis and isolation, thereby preventing secondary transmission (4).

Ingestion of fruit coming in contact with the saliva of bats or inhalation of tiny droplets produced from the infected urine or saliva of the bats residing at the tops of trees can be an important mode of transmission of $\mathrm{NiV}$ to humans. Even though the route of infection of the index case-patient in this outbreak was unknown, further 
investigation is needed to determine how contaminated fruit can be a route of $\mathrm{NiV}$ transmission. High positivity in bats shows the epizootic of NiV infection. Health education and community awareness are needed to break the chain of $\mathrm{NiV}$ transmission.

\section{Acknowledgments}

We gratefully acknowledge the encouragement and support extended by Balram Bhargava. We also thank K.G. Sajeeth Kumar for coordinating and sending clinical samples of NiV case-patients. We thank the dedicated staff of the Biosafety Level 4 facility at ICMR-NIV, especially Sreelekshmy Mohandas, Shilpi Jain, T.P. Majumdar, Savita Patil, Sanjay Gopale, P. Kore, Ganesh Chopade, A. Srivastava, Sheetal Melag, Yogita Chopade, Swapnil Patil, and Vinod Kumar Soman, for their technical support and R. Laxminarayanan for administrative support during the study.

Financial support was provided by intramural funding of the ICMR-NIV.

\section{About the Author}

Dr. Yadav is a group leader for the maximum containment laboratory, ICMR-NIV, Pune, India. Her primary research interests include new pathogen discovery and emerging and reemerging zoonotic diseases of high-risk viruses, including Crimean-Congo hemorrhagic fever, Kyasanur Forest disease, and Nipah.

\section{References}

1. Chan YP, Chua KB, Koh CL, Lim ME, Lam SK. Complete nucleotide sequences of Nipah virus isolates from Malaysia. J Gen Virol. 2001;82:2151-5. http://dx.doi.org/10.1099/ 0022-1317-82-9-2151

2. Lo MK, Lowe L, Hummel KB, Sazzad HMS, Gurley ES, Hossain MJ, et al. Characterization of Nipah virus from outbreaks in Bangladesh, 2008-2010. Emerg Infect Dis. 2012;18:248-55. http://dx.doi.org/10.3201/eid1802.111492

3. Rahman MA, Hossain MJ, Sultana S, Homaira N, Khan SU, Rahman M, et al. Date palm sap linked to Nipah virus outbreak in Bangladesh, 2008. Vector Borne Zoonotic Dis. 2012;12:65-72. http://dx.doi.org/10.1089/vbz.2011.0656
4. Sazzad H. Nipah outbreak in Faridpur District, Bangladesh, 2010. Health Sci Bull. 2010;8:6-11.

5. Chadha MS, Comer JA, Lowe L, Rota PA, Rollin PE, Bellini WJ, et al. Nipah virus-associated encephalitis outbreak, Siliguri, India. Emerg Infect Dis. 2006;12:235-40. http://dx.doi.org/10.3201/ eid1202.051247

6. Arankalle VA, Bandyopadhyay BT, Ramdasi AY, Jadi R, Patil DR, Rahman M, et al. Genomic characterization of Nipah virus, West Bengal, India. Emerg Infect Dis. 2011;17:907-9. http://dx.doi.org/ 10.3201/eid1705.100968

7. Kawada J, Okuno Y, Torii Y, Okada R, Hayano S, Ando S, et al. Identification of viruses in cases of pediatric acute encephalitis and encephalopathy using next-generation sequencing. Sci Rep. 2016;6:33452. http://dx.doi.org/10.1038/srep33452

8. Harcourt BH, Tamin A, Ksiazek TG, Rollin PE, Anderson LJ, Bellini WJ, et al. Molecular characterization of Nipah virus, a newly emergent paramyxovirus. Virology. 2000;271:334-49. http://dx.doi.org/10.1006/viro.2000.0340

9. Luby SP, Hossain MJ, Gurley ES, Ahmed BN, Banu S, Khan SU, et al. Recurrent zoonotic transmission of Nipah virus into humans, Bangladesh, 2001-2007. Emerg Infect Dis. 2009;15:1229-35. http://dx.doi.org/10.3201/eid1508.081237

10. Epstein JH, Prakash V, Smith CS, Daszak P, McLaughlin AB, Meehan G, et al. Henipavirus infection in fruit bats (Pteropus giganteus), India. Emerg Infect Dis. 2008;14:1309-11. http://dx.doi.org/10.3201/eid1408.071492

11. Yadav PD, Raut CG, Shete AM, Mishra AC, Towner JS, Nichol ST, et al. Detection of Nipah virus RNA in fruit bat (Pteropus giganteus) from India. Am J Trop Med Hyg. 2012; 87:576-8. http://dx.doi.org/10.4269/ajtmh.2012.11-0416

12. Yadav P, Sudeep A, Gokhale M, Pawar S, Shete A, Patil D, et al. Circulation of Nipah virus in Pteropus giganteus bats in northeast region of India, 2015. Indian J Med Res. 2018;147:318-20. http://dx.doi.org/10.4103/ijmr.IJMR_1488_16

13. Arunkumar G, Chandni R, Mourya DT, Singh SK, Sadanandan R, Sudan P, et al.; NIPAH: Nipah Investigators People And Health. Outbreak investigation of Nipah virus disease in Kerala, India, 2018. J Infect Dis. 2018;:26; Epub ahead of print.

14. Chua KB, Bellini WJ, Rota PA, Harcourt BH, Tamin A, Lam SK, et al. Nipah virus: a recently emergent deadly paramyxovirus. Science. 2000;288:1432-5. http://dx.doi.org/10.1126/science.288.5470.1432

15. Yadav PD, Albariño CG, Nyayanit DA, Guerrero L, Jenks MH, Sarkale P, et al. Equine encephalosis virus in India, 2008. Emerg Infect Dis. 2018;24:898-901. http://dx.doi.org/10.3201/ eid2405.171844

Address for correspondence: Devendra T. Mourya, Indian Council of Medical Research-National Institute of Virology, 20-A, Dr. Ambedkar Road, Pune, Maharashtra, Pin 411001, India; email: dtmourya@gmail.com 